Kinestetik : Jurnal Ilmiah Pendidikan Jasmani 5 (3) (2021)

Kinestetik : Jurnal Ilmiah Pendidikan Jasmani

https://ejournal.unib.ac.id/index.php/kinestetik/index

DOI : 10.33369/jk.v5i3.17763

\title{
NEEDS ANALYSIS OF DEVELOPMENT DIGITAL-BASED PHYSICAL FITNESS TEST APPLICATION
}

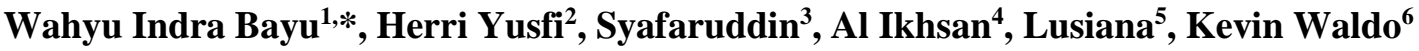 \\ ${ }^{1236}$ Department of Sport Education, FKIP, Universitas Sriwijaya, Palembang, Indonesia \\ ${ }^{245}$ Department of Physical Education and Health, FKIP, Universitas Sriwijaya, Palembang, \\ Indonesia
}

\section{Article Info}

Article History :

Received : September 2021

Revised : September 2021

Accepted : September 2021

Available online : September

2021

Keywords:

Needs Analysis, Development Research, Physical Fitness, Physical Education, Test, Measurement

\begin{abstract}
This article aims to describe a needs analysis related to the development of a digital-based physical fitness test application. This physical fitness test application will later help physical education teachers to be able to evaluate the physical fitness of students. The target respondents in this study were students and physical education teachers in South Sumatra. The results showed that, from 115 respondents who filled out questionnaires distributed online via google form, it showed that $105(91.30 \%)$ respondents had done physical fitness tests to students, $3(2.61 \%)$ respondents had never, and 7 (6.09\%) respondents answered maybe. And 103 (89.57\%) respondents want the development of test and measurement applications related to physical fitness, $2(1.74 \%)$ respondents think "no", and $10(8.70 \%)$ respondents think "maybe". The conclusion of this study is the need for a digital-based physical fitness test and measurement application, either in the form of a website or mobile application.
\end{abstract}

\footnotetext{
Corresponding address : Jl. Srijaya Negara, Bukit Besar, Palembang, Sumatera Selatan, 30139

*Corresponding email : wahyu.indra@fkip.unsri.ac.id
} 


\section{INTRODUCTION}

Technology has developed in various sectors, including education and learning. Technology is changing many things in schools, including physical education learning. (Juniu, 2011), argues that technology can help students experience physical education learning to change their inactive lifestyle into an active and physically fit lifestyle.

Technology is like two sides of a coin, there are contradictions regarding technology support for physical education teachers, because physical education teachers fail to provide arguments and concrete examples of technology support in physical education learning (Wyant \& Baek, 2019). (Enright \& Gard, 2016) states that there are concerns with the use of digital technology in physical education and how it can marginalize the role of physical education teachers.

Integrating technology can be more difficult in some school classrooms than in others. Physical education classes are an example of such a class. Another thing that (Mohnsen, 2012) points out in his book is that specific studies for technology in physical education have been limited and further research is urgently needed in this area. One of the main objectives of learning physical education is to improve and maintain the level of physical fitness of students. Teachers are required to be able to provide learning oriented to physical activity to support the fitness of the students.
Some technologies can be integrated into physical education classrooms, but physical education teachers have a hard time finding great technology that helps their students learn and at the same time doesn't distract from the lesson. But (Baek et al., 2018), reveals that the reason physical education teachers struggle to implement technology is access to technology is the lack of training and time to learn, and the perceived value of technology integration.

Physical Education teachers struggle to implement technology for a variety of reasons. (Wyant \& Baek, 2019), explained the reasons teachers struggle to implement technology are as follows: technology is a distraction for students, teachers need more professional development, and technology can affect the timing and flow of lessons. Using the right technology, being trained properly, and planning lessons can help avoid these difficulties and enable teachers to apply technology to the classroom.

The purpose of this study was to determine the need for technology for physical education teachers to help manage learning. It is important to have technology in the physical education classroom because it motivates and energizes students and allows students to further connect the physical education classroom with the outside world, (McVicker, 2018).

\section{METHODS}

This research is a survey research using a non-structural questionnaire 
which has been prepared to be filled in by the research subjects. Eight questions were compiled in this research questionnaire to find out how big the need for physical fitness test applications with digital results.

Table 1. Questions on the questionnaire used

\begin{tabular}{|c|c|}
\hline No. & Question \\
\hline 1 & $\begin{array}{l}\text { Do you know about the main duties } \\
\text { of a Physical Education Teacher? }\end{array}$ \\
\hline 2 & $\begin{array}{l}\text { If you are a Prospective Physical } \\
\text { Education Teacher/Teacher, are you } \\
\text { sure you can become a good and } \\
\text { right physical education teacher? }\end{array}$ \\
\hline 3 & $\begin{array}{l}\text { If you are a Prospective Teacher / } \\
\text { Physical Education Teacher, do you } \\
\text { know what will be evaluated for } \\
\text { students? }\end{array}$ \\
\hline 4 & $\begin{array}{l}\text { One of the duties of a physical } \\
\text { education teacher is to evaluate the } \\
\text { physical fitness of students, have } \\
\text { you ever conducted a physical } \\
\text { fitness test on students? }\end{array}$ \\
\hline 5 & $\begin{array}{l}\text { What types of physical fitness tests } \\
\text { do you use to evaluate the physical } \\
\text { fitness of students? }\end{array}$ \\
\hline 6 & $\begin{array}{l}\text { With so many types of physical } \\
\text { fitness tests, do you think } \\
\text { standardization is needed in } \\
\text { measuring the physical fitness of } \\
\text { students? }\end{array}$ \\
\hline 7 & $\begin{array}{l}\text { In conducting the physical fitness } \\
\text { test, is it necessary to have a } \\
\text { supporting application (website } \\
\text { and/or mobile application) that is } \\
\text { used as a guide for the } \\
\text { implementation of the physical } \\
\text { fitness test? }\end{array}$ \\
\hline 8 & $\begin{array}{l}\text { If there is an application that } \\
\text { supports physical fitness tests, are } \\
\text { you willing to participate in } \\
\text { socialization and training activities } \\
\text { to use the application, and apply it to } \\
\text { your students? }\end{array}$ \\
\hline
\end{tabular}

Purposive accidental sampling was applied to obtain research data with the research subjects being students and teachers of physical education in South Sumatra. The questionnaire was sent as a link via a google form with the link https://forms.gle/eNNyyZEX7EVkFVvA 6 conducted in August 2021. Participants in this study received information at the beginning of the questionnaire about the purpose of the survey and informed consent. Participants gave an assessment according to the actual situation, and they agreed to participate in this study. The average time needed to answer the questionnaire is five minutes. Statistical analysis used is descriptive data from the results of respondents' answers to the questionnaires that have been sent.

Table 2. Descriptive Characteristics of Respondents

\begin{tabular}{lcc}
\hline Characteristics & Count & N(\%) \\
\hline Gender & & \\
\hline Man & 86 & $74,78 \%$ \\
\hline Woman & 29 & $25,22 \%$ \\
\hline $\begin{array}{l}\text { Respondent } \\
\text { Cluster }\end{array}$ & & \\
\hline $\begin{array}{l}\text { Physical } \\
\text { Education } \\
\text { Student }\end{array}$ & 107 & $93,04 \%$ \\
\hline $\begin{array}{l}\text { Physical } \\
\text { Education } \\
\text { Teacher }\end{array}$ & 8 & $6,96 \%$ \\
\hline
\end{tabular}

\section{RESULTS}

The research data are the results of answers from respondents who filled out a questionnaire sheet via google form on 29-31 August 2021. The results of the respondents' entries will later affect further research in the process of 
developing physical fitness test applications. Table 1 shows the results of the respondents in this study.

Table 3. Results of Respondents

\begin{tabular}{|c|c|c|}
\hline $\begin{array}{l}\text { Do you know about } \\
\text { the main duties of a } \\
\text { Physical Education } \\
\text { Teacher? }\end{array}$ & Jumlah & $\%$ \\
\hline Yes & 112 & $97,39 \%$ \\
\hline No & 0 & $0,00 \%$ \\
\hline Maybe & 3 & $2,61 \%$ \\
\hline $\begin{array}{l}\text { If you are a } \\
\text { Prospective Physical } \\
\text { Education } \\
\text { Teacher/Teacher, are } \\
\text { you sure you can } \\
\text { become a good and } \\
\text { right physical } \\
\text { education teacher? }\end{array}$ & Jumlah & $\%$ \\
\hline Yes & 104 & $90,43 \%$ \\
\hline No & 0 & $0,00 \%$ \\
\hline Maybe & 11 & $9,57 \%$ \\
\hline $\begin{array}{l}\text { If you are a } \\
\text { Prospective Teacher } \\
\text { / Physical Education } \\
\text { Teacher, do you } \\
\text { know what will be } \\
\text { evaluated for } \\
\text { students? }\end{array}$ & Jumlah & $\%$ \\
\hline Yes & 111 & $96,52 \%$ \\
\hline No & 1 & $0,87 \%$ \\
\hline Maybe & 3 & $2,61 \%$ \\
\hline $\begin{array}{l}\text { One of the duties of } \\
\text { a physical education } \\
\text { teacher is to evaluate } \\
\text { the physical fitness } \\
\text { of students, have you } \\
\text { ever conducted a } \\
\text { physical fitness test } \\
\text { on students? }\end{array}$ & Jumlah & $\%$ \\
\hline Yes & 105 & $91,30 \%$ \\
\hline No & 3 & $2,61 \%$ \\
\hline Maybe & 7 & $6,09 \%$ \\
\hline $\begin{array}{l}\text { What types of } \\
\text { physical fitness tests } \\
\text { do you use to } \\
\text { evaluate the physical } \\
\text { fitness of students? }\end{array}$ & Jumlah & $\%$ \\
\hline
\end{tabular}

\begin{tabular}{|c|c|c|}
\hline $\begin{array}{l}\text { Indonesian Physical } \\
\text { Fitness Test (IPFT) }\end{array}$ & 88 & $76,52 \%$ \\
\hline $\begin{array}{l}\text { Bleep Test/Pacer } \\
\text { Run Test/Multistage } \\
\text { Fitness Test/20- } \\
\text { metet shuttle run test }\end{array}$ & 22 & $19,13 \%$ \\
\hline FitnessGram & 5 & $4,35 \%$ \\
\hline EuroFit & 0 & $0,00 \%$ \\
\hline $\begin{array}{l}\text { What types of } \\
\text { physical fitness tests } \\
\text { do you use to } \\
\text { evaluate the physical } \\
\text { fitness of students? }\end{array}$ & Jumlah & $\%$ \\
\hline
\end{tabular}

\begin{tabular}{lcc}
\hline Yes & 103 & $89,57 \%$ \\
\hline No & 2 & $1,74 \%$ \\
\hline Maybe & 10 & $8,70 \%$ \\
\hline
\end{tabular}

If there is an

application that

supports physical

fitness tests, are you

willing to participate

in socialization and

Jumlah $\%$

training activities to

use the application,

and apply it to your

students?

\begin{tabular}{lcc}
\hline Ready & 106 & $92,17 \%$ \\
\hline No & 0 & $0,00 \%$ \\
\hline Maybe & 9 & $7,83 \%$ \\
\hline
\end{tabular}

\section{DISCUSSION}

The results showed that physical education teachers needed technology to assist their task in managing learning. One of the tasks that must be done by the teacher is to evaluate the learning outcomes of students. One that must be evaluated is related to physical fitness.

Physical education and fitness assessments offer learners the opportunity to assess, track, and improve their fitness levels. Physical education teachers can integrate physical fitness tests into instruction as a link between fitness, health, and physical activity. Sharing the results of individual student 
assessments with parents can help increase parental awareness and involvement in the overall health of students.

Physical fitness is a person's ability to carry out activities regularly with enthusiasm and prudence, not to get tired easily, and still have sufficient energy reserves to enjoy free time and prepare for emergencies (Pangrazi \& Beighle, 2016). Physical education teachers must not only have instructional strategies on fitness education, ways to identify students' physical fitness and activity achievements (Pangrazi et al., 2020), and communication tools to increase awareness and understanding of fitness education and its assessment process (Morgan et al., 2004), but also must have ways to evaluate students' physical fitness (Yildiz, 2013).

However, how is technology applied to physical education courses? This can actually be a huge advantage. Many middle and junior high school students, and in some cases, younger students, always carry a smartphone with them. This reality is part of today's evolving society which places great emphasis on connectivity. Learners often see mobile devices as extensions of themselves. Smartphone usage isn't going to diminish any time soon, so it makes sense to take advantage of the power of these devices.

Applications involving video and image analysis can be used to examine athletic movements (Pereira et al., 2014), and ultimately help improve physical skills (Hoyos Cillero \& Jago, 2010). This article shows that there is a need for technology to be applied in evaluating the physical fitness of students. With the right technology in evaluating physical education learning has changed the way we collect and evaluate data on individual students. Not only evaluate, but also provide feedback from daily activities. All of these activities can be carried out with the help of technological tools such as pedometers, smartwatches, and heat rate monitors which are increasingly being used (Craig et al., 2010). With this technology, students will be able to track and analyze their heart rate, activity level, or the number of steps they need to take within a certain time frame.

\section{CONCLUSION}

The explosion of mobile technology has provided physical education teachers with many tools. There are many applications to take advantage of, with some allowing movement tracking and nutritional assistance, while others helping to improve physical activity or sport skills. We all know that the use of technology in learning is a big focus for schools. Physical fitness measurement applications will also provide many benefits, not only for physical education teachers, but also for students and parents. This is related to physical fitness data that can be stored on each student's smartphone. With this data, they can analyze each other's physical fitness and do some problem solving to maintain and improve their fitness level. The mindset that students have like that can be used 
not only to improve their physical fitness, but can also provide lifelong lessons about being responsible for their own health. If we can get students excited about how technology can improve their health and well-being, then we've provided valuable lessons that will help them grow into adulthood. However, these results are not used as a comparison between students.

\section{ACKNOWLEDGEMENT}

The research/publication of this article was funded by DIPA of Public Service Agency of Universitas Sriwijaya 2021. SP DIPA-023.17.2.677515/2021, On November 23, 2020. In accordance with the Rector's Decree Number: 0022/ UN9/ SK.LP2M.PT/2021, On July 21, 2021.

\section{REFERENCES}

Baek, J.-H., Keath, A., \& Elliott, E. (2018). Physical Education Teachers' Technology Practices and Challenges. International Journal of Human Movement Science, 12(2), 27-42. https://doi.org/10.23949/ijhms.2018.08. 12.2.2

Craig, C. L., Tudor-Locke, C., Cragg, S., \& Cameron, C. (2010). Process and treatment of pedometer data collection for youth: The canadian physical activity levels among youth study. Medicine and Science in Sports and Exercise, 42(3), 430-435.

https://doi.org/10.1249/MSS.0b013e31 $81 \mathrm{~b} 67544$

Enright, E., \& Gard, M. (2016). Media, digital technology and learning in sport: a critical response to Hodkinson, Biesta and James. Physical Education and Sport Pedagogy. https://doi.org/10.1080/17408989.2015. 1043258

Hoyos Cillero, I., \& Jago, R. (2010).
Systematic review of correlates of screen-viewing among young children. Preventive Medicine, 51(1), 3-10. https://doi.org/10.1016/j.ypmed.2010.0 4.012

Juniu, S. (2011). Pedagogical Uses of Technology in Physical Education. Journal of Physical Education, Recreation \& Dance, 82(9), 41-49. https://doi.org/10.1080/07303084.2011. 10598692

Lloyd, M., Colley, R. C., \& Tremblay, M. S. (2010). Advancing the debate on "fitness testing" for children: Perhaps we're riding the wrong animal. Pediatric Exercise Science, 22(2), 176-182. https://doi.org/10.1123/pes.22.2.176

McVicker, D. (2018). How technology changes Physical Education classes. G2 Learn Hub. https://learn.g2.com/technology-inphysical-education

Mohnsen, B. (2012). Implementing Online Physical Education. Journal of Physical Education, Recreation \& Dance, 83(2), 42-47.

https://doi.org/10.1080/07303084.2012. 10598727

Morgan, C. F., Beighle, A., Pangrazi, R. P., \& Pangrazi, D. (2004). Children' s Fitness Using Self-Assessment for Personal Fitness Evaluation. Teaching Elementary Physical Education, 15(1), 19-22.

http://www.humankinetics.com/acucust om/sitename/Documents/DocumentIte m/6623.pdf

Pangrazi, R. P., \& Beighle, A. (2016). Dynamic Physical Education for Elementary School Children (18th editi). Pearson Education, Inc.

Pangrazi, R. P., Beighle, A., Shawley, J. M., Corte, M., \& Nichols, C. (2020). Physical Activity and Learning: The Ingredients of a Quality Lesson. In 2020 SHAPE America National Convention \& Expo. SHAPEAMERICA. https://shapeamerica.confex.com/shape america/2020/meetingapp.cgi/Session/4 006

Pereira, J., Hastie, P., Araújo, R., Farias, C., Rolim, R., \& Mesquita, I. (2014). A comparative study of students' track and 
field technical performance in sport education and in a direct instruction approach. Journal of Sports Science and Medicine, 14(1), 118-127.

Wyant, J., \& Baek, J. H. (2019). Re-thinking technology adoption in physical education. Curriculum Studies in Health and Physical Education, 10(1), 3-17. https://doi.org/10.1080/25742981.2018. 1514983

Yildiz, Ö. (2013). Physical education teachers' performance evaluation. Life Science Journal, 10(1), 796-803. https://doi.org/10.7537/marslsj100113.1 25 